\title{
JELE
}

Journal ofEnglish Languageand Education

\section{Editorial Team}

\author{
Editor-in-Chief $\quad$ : Elysa Hartati, S.Pd., M.Pd. \\ Managing Editors $\quad$ : Restu Arini, S.Pd., M.Pd. \\ Editorial Board $\quad$ : Prof. Dr. Soepomo Poedjosoedarmo (Gadjah Mada University) \\ Dr. Issy Yuliasri, M.Pd. (State University of Semarang) \\ Drs. Barli Bram, M.Ed,Ph.D (Sanata Dharma University) \\ Dr. Dwi Anggani L.B., M.Pd. (State University of Semarang) \\ Sayit Abdul Karim, M.Pd.(Technology University of Yogyakarta) \\ Dr. Hermayawati, M.Pd (Mercu Buana University of Yogyakarta) \\ Section Editor $\quad$ : Agustinus Hary Setyawan, Mercu Buana University of Yogyakarta \\ Wilujeng Asih Purwani, Mercu Buana University of Yogyakarta \\ Ika Kurniawati, Mercu Buana University of Yogyakarta \\ ISSN \\ : 2460-7142 (Print) \\ 2541- 6421 (Online) \\ Address $\quad:$ English Education Study Program \\ Faculty of Teachers Training and Education \\ Mercu Buana University of Yogyakarta \\ J1. Wates Km.10 Yogyakarta 55753 \\ Phones \\ : (0274) 6498211, 6498212 \\ Fax \\ : (0274) 6498213 \\ Email \\ : jurnal.umby@gmail.com
}

Journal of English Language and Education (JELE), to appear twice a year (in June and December) for lecturers, teachers and students, is published by the Unit of Scientific Publishing and Intellectual Property Rights, Mercu Buana University of Yogyakarta. This journal welcomes articles which have never been published elsewhere and are not under consideration for publication in other journals at the same time.Articles should be original and typed, 1.5 spaced, about 10-20 pages of quarto-sized (A4), and written in English. For the brief guidelines, it is attached in the end of this journal. 


\section{PREFACE}

We proudly present a Journal of English Language and Education (JELE) Vol.2 No.2, which is envisioned to represent the growing needs of linguistics, literature, and education in English. This journal is written by practitioners and researchers to share their knowledge and solution in the area, to identify new issues and to shape future directions for research.

This journal comprises seven articles dealing with linguistics, literature and English education. They are categorized into pragmatic analysis, English literature, technology development in teaching, and techniques as well as approaches that lead to English teaching development.

This journal would not have been possible without the great support of the Editorial Board members; hence, we would like to express our sincere thanks to all of them. We also would like to thank to all writers who have contributed to this journal content. It is our hope that this fine collection of articles will be a valuable resource for English language and education readers and will stimulate further research into the area.

Yogyakarta, December 2016

Editor 


\section{DAFTAR ISI}

\section{Halaman}

Editorial Team ................................................................................. ii

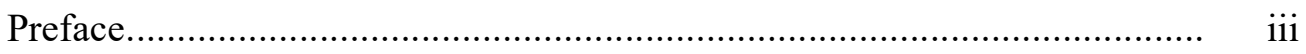

Table of content f.......................................................................... iv

Class Struggle As Represented By The Character Eloi And Morlock In Hebert George Wells' The Time Machine

Putri Praciana Noviyandini ..... 65-73

Developing Test For Experimental Study: The Effectiveness Of Hedwig Strategy In English Education Department Universitas Brawijaya

Devinta Puspita Ratri, Yulia Hapsari, Sugeng Susilo Adi

The Implementation Of Demonstration Strategy Using Modeling Videos

To Improve Confidence And Practices In Presentation

Dewi Anggraeni.

A Video For Teaching English Tenses

Frida Unsiah, Putu Dian Danayanti Degeng, Irene Nany Kusumawardani.... 96-109

Flouting Maxim By Sherlock Holmes And Dr. Watson In Tv Series Of Sherlock Season 1

Lina Affifatusholihah, Agustinus Hary Setyawan

Improving Students' Reading Skill By Using Quantum Learning

Wini Martika, Hermayawati

Social Class Conflict Presented In "The Kite Runner" Novel Based On Marxism Theory

Yohanes Eko Rubiyanto 125-132

Notes for contributors 133 


\title{
FLOUTING MAXIM BY SHERLOCK HOLMES AND DR. WATSON IN TV SERIES OF SHERLOCK SEASON 1
}

\author{
Lina Affifatusholihah ${ }^{1}$, Agustinus Hary Setyawan ${ }^{2}$ \\ ${ }^{12}$ English Education Department, Faculty of Teacher Training and Education \\ Mercu Buana University of Yogyakarta, Indonesia \\ ${ }^{1}$ lina.8493@gmail.com \\ 2agustinushary@gmail.com
}

\begin{abstract}
In running daily activities, people will always meet and interact with other people, and language is a medium that is used by humans to interact with each other. In a conversation or discussion, everyone should pay attention to the four maxims in order that there are no errors in communication. However, it is not uncommon that the four rules above are breached by the speakers. This is called non-observance of the maxims, and one of a non-observance of the maxims that often occurs in is flouting maxim. The aims of this paper are to describe types of maxims that are flouted by Sherlock Holmes and dr. Watson as well as to describe how the maxims are flouted in Sherlock TV series season 1. This research used qualitative descriptive method. The researcher classifies the utterances to know what kind of maxim which are flouted, categorizes those into the category based on the Grice's theory of Cooperative Principle, namely: maxim of quantity, quality, relation and manner. The research procedure begin by searching the script in the internet, matching the utterances in the script and in film and sorting the utterances between Sherlock Holmes and dr. Watson as well observing every word or sentence which are flouted by the main characters. The findings find that all kinds of maxims are flouted by Sherlock and dr. Watson. The result of analysis shows that the maxim flouted when the speakers say something irrelevant; something roguishness or lied to hide the truth in the form of rhetorical question; the information becomes more or too informative than what is required; and something obscurity of expression, ambiguity, or unnecessary prolixity.
\end{abstract}

Keyword: flouting maxim, grice's theory, sherlock tv series, qualitative research.

\section{INTRODUCTION}

Language is divided into two, namely spoken and written. Spoken language is more basic and more natural than written language as it is more spontaneous in use and more widespread. One of the forms of spoken language is conversation. There have to be speakers and listeners involved in a conversation and generally, they are cooperating each other in order to make their conversation succeed (Yule, 1996).

To make conversation succeed we must understand the language. Language as a means of communication, has a very important role in human daily life. In running daily activities, people will always meet and interact with other people, and language is a medium that is used by humans to interact with each other. In normal communication, speaker and hearer will always try to convey speech effectively and efficiently. Everybody needs to communicate to others by using language to express their ideas, thoughts, feelings, and knowledge. A good communication is needed for everyone in interaction with others in order the communication run well and effectively because it can avoid misunderstanding and misinterpret between the speaker and the hearer (Tarigan, 1984).

Avoiding the misunderstanding and misinterpreting in communication, the most salient part of human communication is 
epitomized in a conversation. The conversation itself, as a reciprocal act, retains specific rules and regulations. For the most part, it incorporates topic nomination, turntaking, negotiation of meaning, etc. (Markee \& Kasper, 2004 in Khosravizadeh and Sadehvandi, 2011). However, to convey the meaning through the medium of communication, speaker should follow certain strategies or what the language philosopher Grice (1975) has termed as cooperative principle. The principle consists of four maxims: quality, quantity, relation, and manner, which represent how people are anticipated to perform in a conversation, in general. In other words, the cooperative principle imposes certain restrictions on participants to adjust their speech in correspondence with the maxims.

The maxims can be flout, it takes place when individuals deliberately cease to apply the maxims to persuade their listeners to infer the hidden meaning behind the utterances; that is, the speakers employ implicature (Levinson, 1983 in Khosravizadeh and Sadehvandi, 2011). In the case of flouting of cooperative maxims, the speaker desires the greatest understanding in his/her recipient because it is expected that the speaker is able to uncover the hidden meaning behind the utterances. People may flout the maxim of quality so as to deliver implicitly a sarcastic tone in what they state.

In an interaction, breach of maxims are often inevitable. These flouting could have been done by the speaker or hearer intentionally or unintentionally. Flouting of the Grice's cooperation principle occur if one of the speakers did not provide actual information, or in other words not to be working properly. Flouting of the Grice's cooperation principle consists of flouting of the maxim of quality, flouting of the maxim of quantity, flouting of the maxim of relation, and flouting of the maxims of manner.

In a conversation or discussion, everyone should pay attention to the fourth maxim in order that there is no error in communication. However, it is uncommon that the four rules above are breached by the speakers. This is called non-observance of the maxims, and one of a non-observance of the maxims that often occurs is flouting maxim. Flouting is one of maxim offense that is very common and has several categories. Flouting happens where the speaker blatantly failed to deliver something to the speaker. Usually the violations that occurred was intentional by the speaker. The speaker just want the listener to look for other meanings of the words, which flouted the maxim (Adinda, 2012). Flouting maxim often happens in everyday life as a simple example:

A: Is there another pint of milk?

B: I'm going to the supermarket in five minutes.

In a conversation between $\mathrm{A}$ and $\mathrm{B}$ above, BB did not answer the relevant questions of $\mathrm{A}$. This is an example of the flouting maxim of relation, with which a person does not provide relevant answers to 
the questioner. The conversations as the above example happens in our daily life.

Film is a medium of mass communication or the communication through the mass media. In addition to electronic media and print media such as television, radio, internet, newspapers, magazines, and so on, film also serves as a mean to convey message to the public. Film can be described as the transformation of people's lives, because the film is a portrait of a society in which the film was made. As the mass media, the film is effective in providing information and undertake the representation of reality to a mass audience because it is audio-visual.

The film represents the daily life because of the inspiration of the film comes from events in human life. Similarly Sherlock Holmes movie is an adaptation of the book of the Scottish author Sir Arthur Conan Doyle, who created the profession of the world's first consulting detective. A detective who is known genius and logic as well as master of disguise, a great observer and expert deductive inference, which means to draw general conclusions from small things. According to Doyle, the character was inspired by the Dr. Joseph Bell, professor of medicine in college (Prabawa, 2012).

Sherlock TV series (Kemala, 2014) is a British crime drama television series and a contemporary adaptation of Sir Arthur Conan Doyle's Sherlock Holmes detective stories. The first season was broadcasted in 2010. The first season has three episodes, namely; The first episode, "Study in Pink", depicts the introduction of Holmes to Watson, and they entering a flat share at Baker Street in London, and then their investigation into a series of deaths, initially believed to be suicides; "The Blind Banker", depicts Holmes being hired by an old university acquaintance to investigate a mysterious break-in at a bank in the City; and lastly "The Great Game", introduces the character of archenemy, James Moriarty, to the series, who sets Holmes deadlines to solve a series of apparently unrelated cases.

In Sherlock TV series, there are several flouting maxim, for example from Sherlock TV series Study in Pink script taken from DeVere, A. (2012):

BART'S LAB. Sherlock is standing at the far end of the lab using a pipette to squeeze a few drops of liquid onto a Petri dish. Mike knocks on the door and brings Dr. Watson in with him. Sherlock glances across at them briefly before looking at his work again. Dr. Watson limps into the room, looking around at all the equipment.

DR. WATSON : How did you know about Afghanistan?

(Sherlock ignores the question, wraps his scarf around his neck, then picks up his mobile and checks it.)

SHERLOCK : Got my eye on a nice little place in central London. Together we ought to be able to afford it.

(He walks towards Dr. Watson.)

SHERLOCK : We'll meet there tomorrow evening; seven o'clock. Sorry - gotta dash. I 
think I left my riding crop in the mortuary.

(Putting his phone into the inside pocket of his coat, he walks past Dr. Watson and heads for the door.)

The example from Sherlock TV series the first episode, entitled "A Study in Pink", above shows that Sherlock did the flouting of relation maxim. Sherlock ignored dr. Watson's questions and said something that is irrelevant to dr. Watson's question. Therefore, the researchers found it necessary to examine the flouting maxim in Sherlock TV series.

Theoretically, the researcher feels that still need to examine the Grice's maxim theory in order to corroborate the theory. Methodologically, based on previous studies that discuss cooperative principles Grice's theory, many of them observe hedging, violating and so on. Thus in this study, researcher examined flouting maxim based on cooperative principles of Grice's theory. Empirically, the previous study, some context is a humor and romantic movie. Intended for this study using different context from the previous context that is crime drama television series. The aim of this paper is to examine how the maxims are flouted in Sherlock TV series season 1 because flouting maxim in crime drama never been studied before.

Based on the description above, the writer is interested to conduct an analysis of floating maxim, which exists in the "Sherlock TV series season 1", under the title of
"Flouting maxim by Sherlock Holmes and dr. Watson in Sherlock TV series season 1".

\section{METHOD}

This research uses pragmatic analysis to describe how the maxims are flouted by the main characters on Sherlock TV series season 1. The researcher collected the data from the Sherlock TV series' and helped with the script from the series, which was taken from http://arianedevere.livejournal.com/. The data were all the utterances by the main characters of Sherlock TV series season 1, namely Sherlock Holmes and dr. Watson.

This research uses qualitative methodology in analyzing the data. In qualitative studies, the human investigator is the primary instrument for gathering and analyzing the data. In qualitative research, which became the research instrument or tool is the researcher itself therefore the researchers must be validated. Validation of the researchers, include; understanding of qualitative research methods, mastery of knowledge to the field are researched, researcher's readiness to enter the research object both academic and logic (Sugiono, 2011). The researcher observes the utterances produced by the main characters in Sherlock TV series season 1 to get the real and representative data from the original sources or primary data. Then, the researcher watch and look for some utterances which flouted the maxims that are related to the problems of the research.

According to Arikunto (2006) method of documentation is searching for data, 
presentations, meeting minutes, agendas and so on. This method is used to collect data to investigate the documents that already exist and a place to prepare a number of data and information. The script as a data was upload, therefore the documents already exist.

This study is a qualitative form of a description of the aspects of linguistics as a whistleblower culture. Researchers make interpretation of the data has been collected to describe floating maxim that happens. The researcher use descriptive techniques to analyze the collected data. The researcher classifies the utterances to know what kind of maxim are flouted, categorizes those into the category based on the Grice's theory of Cooperative Principle, namely: maxim of quantity, quality, relation and manner, gives the explanation or description and discussion the findings that related to the objectives of the research and the last makes general conclusion from research finding about flouting maxims.

The researcher searched for the script in the internet, watched the series for several times to match the utterances in the script and in film and sorted the utterances between Sherlock Holmes and dr. Watson as well observed every word or sentence which are flouted by the main characters The data in this research is collected by numbering the scene, numbering the utterances, and also noting the time of dialogues. Then, the data taken from two main characters; Sherlock Holmes and dr. Watson are put on the analysis.

\section{FINDINGS AND DISCUSSION}

Sherlock TV series season 1 has three episode namely: Study in Pink, The Blind Banker and The Great Game. In episode 1 entitle Study in Pink, researcher found eleven data that are flout by Sherlock and dr. Watson. In episode 2 entitle The Blind Banker, researcher found fourteen data that are flout by Sherlock and dr. Watson. In episode 3 entitle The Great Game, researcher found twelve data that are flout by Sherlock and dr. Watson. After collecting the data, the researcher found thirty seven data which contain flouting maxim in overall Sherlock TV series season 1.

After obtaining the data, I need to discuss the findings in order to clarify the answers of research questions. Based on the second problem, "How are the maxims flouted by the main characters on Sherlock TV series season 1, I find that the maxims flout when they are delivering and maintaining their opinions, such as by producing the utterance in the form of rhetorical strategies.

Flouting maxim of quality happens in episode 2 and episode 3 and doesn't happen in episode 1. In The Blind Banker, researcher found two data namely: datum 1 and datum 2 and in The Great Game, researcher found three data namely: datum 3, datum 4, and datum 5 . The total is five data included into the type of flouting maxim of quality. The maxim of quality is not to say what you believe to be false" is also flouted when the speaker produces the utterance in the form of rhetorical question. In this case, the speaker signifies that it is not a sincere question. It means that the speaker asks a question without any intention 
of obtaining an answer and it tends to break a sincere condition on question, namely that the speaker wants the hearer to provide him with the indicate information. For example, Sherlock said "Why shouldn't I?" It shows that Sherlock hide something and give a question as a response to $\mathrm{dr}$. Watson's question. This utterance is a flouting maxim of quality.

Flouting maxim of quantity happens in all of episode in Sherlock TV series season 1. In Study in Pink, researcher found only datum 6. In The Blind Banker, researcher found two data namely: datum 7 and datum 8 and in The Great Game, researcher found two data namely: datum 9 and datum 10. The total is five data included into the type of flouting maxim of quantity. The maxim of quantity is flouted when the speaker produces the utterance in the form of overstatement. In this case, the speaker uses exaggerated statement or utterances to convey his opinion which is too strong and appear worse than he really is. Therefore, the information becomes more or too informative than what is required. For example, dr. Watson said 'Lukis' diary. He was here too. He wrote down the address." It shows that dr. Watson give information too much than needed. This utterance is a flouting maxim of quantity.

Flouting maxim of quantity happens in all of episodes in Sherlock TV series season 1. In Study in Pink, researcher found four data namely: datum 11, datum 14, datum 15 and datum 16. In The Blind Banker, researcher found three data namely: datum 12, datum 17 and datum 18. In The Great Game, researcher found four data namely: datum 13, datum 19, datum 20 and datum 21. The total is eleven data included into the type of flouting maxim of manner. The flouting maxim of manner is using complicated constructions when simple ones will do. The maxim of manner is also flouted when the speaker produces the utterance in the form of obscurity of expression, ambiguity, or unnecessary prolixity. For example, Sherlock said "Don't wanna use mine. Always a chance that the number will be recognized. It's on the website." In this case, Sherlock signifies that it is too much information. It means that Sherlock responding a question with many information that is not necessary to be said. This utterance is flouting maxim of manner.

Flouting maxim of quantity happens in all of episode in Sherlock TV series season 1. In Study in Pink, researcher found six data namely: datum 23 , datum 24 , datum 25 , datum 26, datum 27, and datum 28. In The Blind Banker, researcher found seven data namely: datum 29, datum 30, datum 31, datum 22, datum 32, datum 33 and datum 34. In The Great Game, researcher found three data namely: datum 35, datum 36, and datum 37. The total is sixteen data included into the type of flouting maxim of relation. The maxim of relation is relevant. As a Grice writes that flouting maxim is for the fact that subjects of conversations are legitimately changed, and so on. In this case, the speaker responding question with irrelevant answer For example, Sherlock said "Well, this one was quite 
simple, actually, and like I said, the bomber repeated himself. That was a mistake." In this case, Sherlock said irrelevant answer to dr. Watson. It means that the speaker has no any intention to answer the question correctly. This utterance is a flouting maxim of relation.

\section{CONCLUSION}

Based on the research problems in the first chapter and the chapter four findings and discussion, the following conclusion can be described. Dealing with the first question about the kinds of flouting maxims in Sherlock TV series season 1, the analysis finds that all kinds of maxims are flouted by Sherlock and dr. Watson. Flouting maxims of relation was found much more than others flouting maxim in the Sherlock TV series season 1. In this case, the speakers in the movie flouted maxim of relation by saying something irrelevant with the question.

Then, flouting maxims of quality was found in the Sherlock TV series season 1 when the speakers say something to hide the truth fact. Moreover, flouting maxims of quantity was also found in the movie because the speaker made their contribution less informative than required. The last, maxim of manner was found in the Sherlock TV series season 1 when the speaker said something ambiguity and obscurity. Dealing with the second question that is about how are the maxims flouted by the Sherlock Holmes and dr. Watson on Sherlock TV series season 1, the result of analysis shows that the maxim flouted when the speakers said something irrelevant, said something roguishness or lied to hide the truth, said something too informative and said something obscurity and ambiguity.

In this research, the researcher analyzed flouting maxims in Sherlock TV series season 1. Researcher found that all kinds of maxims were flouted. But, this study analyzed utterances which are constructed in crime drama television series. After conducting this study, the researcher suggests the next researcher to do a research about flouting maxim which is done in the other genre of series of movie. The second suggestion for future researcher to consider the violation maxim, infringing and opting out to be observed besides flouting maxim.

A recommendation for English teachers especially in teaching junior high level and senior high level is to provide more practical activities and to involve them directly in the use of the foreign language to interact socially. In this case, the communicative language learning means learning to use the language to interact in a real situation. Teaching a foreign language that gives the opportunity as much as possible to be trained in social interaction on teaching language will better achieve the objectives in accordance with the nature of the language as a communication tool.

Language teaching should be more emphasis on language skills. This is evident from the simple experience in daily life, for example, by analyzing the structure of the language of a movie, novel or a song lyric. This experience to motivate student who is 
learning a foreign language especially English.

Then, one film or series that can make a referral for learning English is Sherlock TV series season 1 that I was analyzed in this research. Flouting maxim also can be a material for teaching students.

\section{REFERENCES}

Adinda, L. (2012). Assignment: PRAGMATICS. Available online at: http://comeplaywithwords.blogspot.co.i d/2012/01/pragmatics.html. [Accessed: November 25, 2015]

Arikunto, S. (2006). Prosedur Penelitian Suatu Pendekatan Praktik. Revision Edition VI. Jakarta: Rineka Cipta.

DeVere, A. (2012). Sherlock - Episode transcripts. Available online at: http://arianedevere.livejournal.com/365 05.html. [Accessed: November 1, 2015]

Grice, H. P. (1975). Logic and conversation. London.

Prabawa, I. (2012). Sherlock Holmes - Sejarah dan Penciptanya. Available online at: https://imanprabawa.wordpress.com/201 2/12/16/sherlock-holmes-sejarah-danpenciptanya/.[Accessed: November 25, 2015]

Khosravizadeh, P. \& Sadehvandi, N. (2011). Some Instances of Violation and Flouting of the Maxim of Quantity by the Main Characters (Barry \& Tim) in Dinner for Schmucks. Available online at:http://sharif.ir/ khosravizadeh/linkfile /violation.pdf. [Accessed: November 25, 2015]
Kemala, A. (2014). Sherlock the series. Available online at: http://thisisannisa.blogspot.co.id/2014/0 9/sherlock-series 8.html. Accessed: November 25, 2015]

Mulyana, D. (2001). Ilmu Komunikasi, Suatu Pengantar. Bandung: Remaja Rosdakarya.

Sugiyono. (2011). Metode Penelitian Kuantitatif, kualitatif dan $R \& D$. Bandung: Alfabeta

Tarigan, H. G. (1984). Prinsip-prinsip dasar sastra. Bandung: Angkasa

Yule, G. (1996). Pragmatics. Oxford: Oxford University Press. 


\section{NOTES FOR CONTRIBUTORS}

Submisions are invited in the following categories:

Manuscript must be a research article that may be submitted by mail, fax, or e-mail. The entire manuscript should be 1.5 spaced on A4 paper, 10-20 pages in length (including references, tables, notes); preferably submitted with its standard formatted for MS Word in 12-point Times New Roman font. Tables and figures (in JPEG or GIFF format) should be set out in separate pages. Number tables and figures and provide captions. Identify where these should appear in the text with an insertion point.

The article should be systematically arranged as follows: (a) title, (b) full name of the contributor with no academic title, institution and email address, (c) abstract (150-250 words), (d) keywords (5 words), (e) introduction covering the background, review of related literature, purpose and scope, (f) methods, (g) findings and discussion, (g) conclusion and suggestion, and $(\mathrm{h})$ references.

All references cited should be listed alphabetically at the end of the article. Here are some examples.

Book:

Brown, H. D. (2000). Principles of Language Learning and Technology. ( $4^{\text {th }}$ ed). New York: Pearson Education, Inc.

\section{Journal Article with Continuous Paging:}

Graham, S. and Sandmel, K. (2011). The process writing approach: A meta-analysis. The Journal of Educational Research, 104, 396-407.
Journal Article when each issue begins with $\mathrm{p.1}$ :

Amogne, D. (2013). Enhancing students ${ }^{\text {ee }}$ writing skills through the genre approach. International Journal of English and Literature, 4(5), 242-248.

Undergraduate Thesis, Thesis, Dissertation:

Qomarudin, A. (2010). Correlation between Extraversion Personality and English Writing Skill. A Thesis. Semarang: Diponegoro University.

Online Article:

Shillaw, J. The Application of Rasch Modelling to Yes/ No Vocabulary Tests. [Online] Retrieved from http://www.scan.ac.uk/cals/cals res/vlibrary/js96a.htm on 12 September 2005.

Contribution and correspondence on editorial matters should be addressed to editor"s address: English Education Study Program, Mercu Buana University of Yogyakarta, Jalan Wates Km. 10, Yogyakarta 55753, Phone (0274) 6498212 Fax (0274) 6498213, Email: jurnal.umby@gmail.com

*The editor reserves the right to compose the manuscript to fit the guidelines or returns it for repair, or rejects it. 